\title{
EFFECT OF MANGANESE ON RATS FED CASEIN DEFICIENT DIET
}

\author{
Satya V. CHANDRA and Ratan S. SRIVASTAVA \\ Industrial Toxicology Research Centre, Post Box No. 80, \\ Lucknow-226001, U.P., India
}

(Received July 8, 1977)

\begin{abstract}
Effect of manganese administration, on the morphology and metal concentration in various tissues of rats fed $10 \%$ casein diet, were investigated. Daily intraperitoneal administration of $\mathrm{MnCl}_{2} \cdot 4 \mathrm{H}_{2} \mathrm{O}(15 \mathrm{mg} / \mathrm{kg})$ to the rats fed $10 \%$ casein diet for a period of 45 days produced almost identical increase in metal concentration of various tissues as after similar treatment to the animals fed basal diet. Protein deficient diet did not alter the extent of manganese induced morphological lesions in various tissues of rats. The data indicated that $10 \%$ casein diet to the adult rats did not make them more susceptible to manganese poisoning.
\end{abstract}

Recent investigations have shown that iron deficiency is one of the metabolic factors responsible to render humans and experimental animals more susceptible to manganese toxicity. ${ }^{1 \sim 3)}$ Several other nutritional factors are known to influence the toxicity of agricultural chemicals, minerals and oxidant air pollutants. Dietary carbohydrates, protein and ascorbic acid affect the toxicity of chromium.4) Toxicity of lead and mercury is also known to alter in presence of certain dietary deficiencies. ${ }^{5,6)}$ Several studies have indicated that protein deficiency in the diet impairs the growth leading to impairment of ability to metabolise toxic chemicals. Thus the understanding of clinicopathological syndrome of manganese toxicity in relation to protein deficiency needs experimentation, particularly in developing countries where the diet is normally low in protein. This study also has an application to exposed humans with low intake of protein due to chronic alcoholism and psychological disturbances. The present communication deals with the observations on clinicopathological effects and manganese accumulation in various tissues of metal exposed rats fed casein deficient diet.

\section{Materials ANd Methods}

\section{Animals}

120 male albino rats weighing $140 \pm 20 \mathrm{~g}$ were obtained from I.T.R.C. colony. They were kept under standard laboratory conditions and fed with synthetic diet and tap water ad libitum. 
Diet

The composition of synthetic basal diet as percentage by weight was based on the formula suggested by Boyd and Taylor (1971). ${ }^{7}$ It contained casein $26 \%$, Corn starch $59 \%$, purified ground nut oil (Postman Brand, India) $8 \%$, Salt mixture $4 \%$ and an all vitamin mixture $3 \%$. When casein was decreased in the diet, the corresponding amount of corn starch was added.

\section{Experiment}

The animals were randomly divided into four groups of 30 rats each and they were treated as follows:

Group 1: Basal diet plus daily intraperitoneal physiological saline $(1 \mathrm{~m} l)$ for 45 days.

Group 2: $10 \%$ casein diet plus similar treatment as in group 1 .

Group 3: Basal diet plus daily intraperitoneal $\mathrm{MnCl}_{2} \cdot 4 \mathrm{H}_{2} \mathrm{O}, 15 \mathrm{mg} / \mathrm{kg}$, for 45 days.

Group 4: $10 \%$ casein diet plus similar treatment as in group 3.

Fortnightly weight records of all the animals was maintained. Mortality among the rats was noted and autopsy was performed on dead animals to ascertain the cause of death. Six animals from each group were sacrificed at the interval of 15 days till the termination of the experiment at 45 days. After gross examination of the body tissues, pieces of lung, heart, liver, pancreas, spleen, kidney, adrenals and testis were fixed for routine histopathological examination. Brain was cut into two halves by median saggital section, one half of it was fixed in buffered formalin while other half of brain and pieces of above mentioned tissues were kept for manganese estimation.

For histopathological studies fixed tissues were processed according to a conventional method. $5 \mu$ thick sections were stained with hematoxylin and eosin.

Manganese estimation was done by the procedure described by Shukla et al. (1976) ${ }^{87}$ using Perkin-Elmer model 303 double beam atomic absorption spectrophotometer equipped with Boling Burner and null read out accessory. Statistical analysis was done by employing the student ' $t$ ' test to calculate the statistical significance between control and experimental values. $\mathrm{P}$ values less than 0.05 were considered significant.

\section{Results}

Table 1 shows the weight and mortality in the animals of all the four groups. The rats fed on basal diet (groups 1 and 3) looked normal and gained weight throughout the experiment, while groups 2 and 4 rats maintained on $10 \%$ casein diet were cachectic and gradually lost weight. Fifty one and 42 percent decrease in the weight of groups 2 and 4 animals respectively was observed at 45 days. Their fur lost healthy appearance and large amounts dropped off. The consumption of food was normal in all the groups. Eleven and 12 rats from groups 2 and 4 respectively died during the course of the experiment. The cause of death of these animals could not be ascertained. Slightly more weight loss and mortality among rats of group IV was not significant statistically from group II rats. 


\section{MANGANESE AND CASEIN DEFICIENT DIET}

Table 1. Weight and mortality of rats.

\begin{tabular}{|c|c|c|c|c|c|c|c|c|}
\hline \multirow{2}{*}{$\begin{array}{l}\text { Duration of } \\
\text { experiment } \\
\text { (Days) }\end{array}$} & \multicolumn{4}{|c|}{ Weight (gm) } & \multicolumn{4}{|c|}{ No. of Deaths } \\
\hline & GR I & GR II & GR III & GR IV & GR I & GR II & GR III & GR IV \\
\hline 0 & $130 \pm 20$ & $135 \pm 20$ & $130 \pm 20$ & $140 \pm 20$ & - & - & - & 一 \\
\hline 15 & $150 \pm 20$ & $115 \pm 15$ & $168 \pm 10$ & $117 \pm 20$ & - & 3 & - & 2 \\
\hline 30 & $210 \pm 15$ & $90 \pm 10$ & $169 \pm 30$ & $75 \pm 15$ & - & 4 & - & 3 \\
\hline 45 & $220 \pm 30$ & $70 \pm 10$ & $180 \pm 25$ & $60 \pm 5$ & - & 4 & - & 7 \\
\hline
\end{tabular}

GR I (30 rats): Basal diet.

GR II (30 rats): $10 \%$ casein diet.

GR III (30 rats): Basal diet+daily i.p. $\mathrm{MnCl}_{2} \cdot 4 \mathrm{H}_{2} \mathrm{O}, 15 \mathrm{mg} / \mathrm{kg}$.

GR IV (30 rats): $10 \%$ casein diet + daily i.p. $\mathrm{MnCl}_{2} \cdot 4 \mathrm{H}_{2} \mathrm{O}, 15 \mathrm{mg} / \mathrm{kg}$.

\section{Morphological alterations}

Administration of manganese chloride to the rats fed basal diet produced mild venous and sinusoidal congestion, tiny areas of focal necrosis of hepatocytes and degenerative changes in the spermatogenic epithelium of a few tubules at 45 days.

Table 2 summarizes the morphological lesions at different time intervals in various organs of rats fed $10 \%$ casein diet (group II). Almost normal morphological architecture of various tissues was observed at 15 days. Protein deficient diet for 30 days produced congestion in liver and kidney. Cytoplasm of the hepatocytes was vacuolated. Degener-

Table 2. Morphological alterations in rats fed $10 \%$ casein diet.

\begin{tabular}{|c|c|c|c|}
\hline \multirow{2}{*}{ Tissues } & \multicolumn{3}{|c|}{ Duration of treatment-days } \\
\hline & 15 & 30 & 45 \\
\hline Brain & N.A. & N.A. & Slight meningeal congestion. \\
\hline Lungs & N.A. & N.A. & N.A. \\
\hline Heart & N.A. & N.A. & N.A. \\
\hline Liver & $\begin{array}{l}\text { Pale cytoplasm of } \\
\text { hepatocytes. }\end{array}$ & $\begin{array}{l}\text { Congestion of central } \\
\text { veins. Vacuolated } \\
\text { cytoplasm. }\end{array}$ & $\begin{array}{l}\text { Marked venous and sinu- } \\
\text { soidal congestion, vacuolated } \\
\text { cytoplasm. Tiny areas of } \\
\text { focal necrosis. }\end{array}$ \\
\hline Spleen & N.A. & N.A. & N.A. \\
\hline Pancreas & N.A. & N.A. & Necrosis in acinar cells. \\
\hline Intestines & N.A. & N.A. & N.A. \\
\hline Kidney & N.A. & Congestion & $\begin{array}{l}\text { Marked congestion, necrosis } \\
\text { of few tubules. }\end{array}$ \\
\hline Adrenals & N.A. & N.A. & N.A. \\
\hline Testis & N.A. & $\begin{array}{l}\text { Degenerative changes } \\
\text { in spermatogenic epi- } \\
\text { thelium in few tubules. }\end{array}$ & $\begin{array}{l}\text { Degenerative changes in } \\
\text { spermatogenic epithelium } \\
\text { in many tubules. }\end{array}$ \\
\hline
\end{tabular}

N.A.: Normal appearance. 


\section{S.V. CHANDRA AND R.S. SRIVASTAVA}

Table 3. Effect of manganese administration on morphological alterations in rats fed $10 \%$ casein diet.

\begin{tabular}{|c|c|c|c|}
\hline \multirow{2}{*}{ Tissues } & \multicolumn{3}{|c|}{ Duration of treatment-Days (Daily i.p. $\mathrm{MnCl}_{2} \cdot 4 \mathrm{H}_{2} \mathrm{O}, 15 \mathrm{mg} / \mathrm{kg}$ ) } \\
\hline & 15 & 30 & 45 \\
\hline Brain & N.A. & N.A. & Mild congestion. \\
\hline Lungs & N.A. & N.A. & N.A. \\
\hline Heart & N.A. & N.A. & N.A. \\
\hline Liver & $\begin{array}{l}\text { Pale cytoplasm of } \\
\text { hepatocytes. }\end{array}$ & $\begin{array}{l}\text { Congestion of central veins } \\
\text { and sinusoids. Vacuolated } \\
\text { cytoplasm, tiny areas of } \\
\text { focal necrosis. }\end{array}$ & $\begin{array}{l}\text { Marked congestion, vacu- } \\
\text { olated cytoplasm, focal } \\
\text { necrosis. }\end{array}$ \\
\hline Spleen & N.A. & N.A. & N.A. \\
\hline Pancreas & N.A. & N.A. & Necrosis of acinar cells. \\
\hline Intestines & N.A. & N.A. & N.A. \\
\hline Kidney & N.A. & Congestion & $\begin{array}{l}\text { Marked congestion, and } \\
\text { tubular necrosis. }\end{array}$ \\
\hline Adrenals & N.A. & N.A. & N.A. \\
\hline Testis & N.A. & $\begin{array}{l}\text { Degeneration of sperma- } \\
\text { togenic epithelium of few } \\
\text { tubules. }\end{array}$ & $\begin{array}{l}\text { Marked degenerative } \\
\text { changes in several } \\
\text { tubules. }\end{array}$ \\
\hline
\end{tabular}

N.A.: Normal appearance.

ative changes in various elements of spermatogenic epithelium was observed in a few tubules. The intensity of morphological lesions enhanced in liver and testis of rats fed $10 \%$ casein diet for 45 days. Congestion and necrosis of tubular cells in kidney and degenerative changes in the cells of pancreatic acini were observed. Other tissues did not show appreciable morphological lesions at this time interval.

Table 3 is a summary of morphological alterations in the tissue of rats administered with manganese chloride and fed $10 \%$ casein diet. Protein deficient diet does not appear to alter the toxicity of manganese in various tissues.

\section{Manganese content in various tissues}

The contents of manganese in brain, heart, liver, pancreas, kidney, adrenal and testis of rats in all the four groups are shown in the Table 4. The two groups (I \& II) without manganese administration had almost the same contents of manganese throughout the experimental period. Daily intraperitoneal administration of manganese chloride to the rats of groups III and IV, fed basal diet and 10\% casein diet respectively, produced significant increase in the metal contents in pancreas and brain at 15 days while in heart, liver, kidneys and testis at 30 days. Significant accumulation of manganese in the adrenals was observed at 45 days. The difference in manganese accumulation in various tissues of these two groups was not found to be statistically significant. 


\section{MANGANESE AND CASEIN DEFICIENT DIET}

Table 4. Effect of manganese administration on its content in various tissues of rats fed $10 \%$ casein diet. ( $\mu \mathrm{g} \mathrm{Mn} / \mathrm{g}$ fresh tissue)

\begin{tabular}{|c|c|c|c|c|c|c|c|c|c|c|}
\hline \multirow{2}{*}{ Tissues } & \multirow{2}{*}{ GR I } & \multicolumn{3}{|c|}{ GR II } & \multicolumn{3}{|c|}{ GR III } & \multicolumn{3}{|c|}{ GR IV } \\
\hline & & $15 \mathrm{D}$ & $30 \mathrm{D}$ & $45 \mathrm{D}$ & $15 \mathrm{D}$ & $30 \mathrm{D}$ & $45 \mathrm{D}$ & $15 \mathrm{D}$ & $30 \mathrm{D}$ & $45 \mathrm{D}$ \\
\hline Brain & $\begin{array}{l}0.33 \pm \\
0.006\end{array}$ & $\begin{array}{l}0.32 \pm \\
0.02\end{array}$ & $\begin{array}{l}0.39 \pm \\
0.03\end{array}$ & $\begin{array}{l}0.33 \pm \\
0.06\end{array}$ & $\begin{array}{l}0.57 \pm \\
0.01^{\mathrm{a}}\end{array}$ & $\begin{array}{l}0.53 \pm \\
0.03^{\mathrm{a}}\end{array}$ & $\begin{array}{l}0.60 \pm \\
0.03^{\mathrm{a}}\end{array}$ & $\begin{array}{l}0.57 \pm \\
0.06^{\mathrm{a}}\end{array}$ & $\begin{array}{l}0.55 \pm \\
0.06^{\mathrm{a}}\end{array}$ & $\begin{array}{l}0.63 \pm \\
0.03^{\mathrm{a}}\end{array}$ \\
\hline Heart & $\begin{array}{l}0.33 \pm \\
0.04\end{array}$ & $\begin{array}{l}0.33 \pm \\
0.03\end{array}$ & $\begin{array}{l}0.39 \pm \\
0.01\end{array}$ & $\begin{array}{l}0.28 \pm \\
0.09\end{array}$ & $\begin{array}{l}0.32 \pm \\
0.01\end{array}$ & $\begin{array}{l}0.48 \pm \\
0.02^{\mathrm{a}}\end{array}$ & $\begin{array}{l}0.72 \pm \\
0.05^{\mathrm{a}}\end{array}$ & $\begin{array}{l}0.39 \pm \\
0.06\end{array}$ & $\begin{array}{l}0.60 \pm \\
0.11^{\mathrm{a}}\end{array}$ & $\begin{array}{l}0.71 \pm \\
0.13^{\mathrm{a}}\end{array}$ \\
\hline Liver & $\begin{array}{l}1.45 \pm \\
0.12\end{array}$ & $\begin{array}{l}1.56 \pm \\
0.06\end{array}$ & $\begin{array}{l}1.16 \pm \\
0.16\end{array}$ & $\begin{array}{l}1.42 \pm \\
0.07\end{array}$ & $\begin{array}{l}1.97 \pm \\
0.05\end{array}$ & $\begin{array}{l}2.13 \pm \\
0.14^{\mathrm{b}}\end{array}$ & $\begin{array}{l}2.28 \pm \\
0.13^{\mathrm{a}}\end{array}$ & $\begin{array}{l}1.89 \pm \\
0.39\end{array}$ & $\begin{array}{l}1.98 \pm \\
0.09^{\mathrm{b}}\end{array}$ & $\begin{array}{l}2.27 \pm \\
0.05^{\mathrm{a}}\end{array}$ \\
\hline Pancreas & $\begin{array}{l}2.31 \pm \\
0.07\end{array}$ & $\begin{array}{l}2.44 \pm \\
0.11\end{array}$ & $\begin{array}{l}2.38 \pm \\
0.08\end{array}$ & $\begin{array}{l}2.51 \pm \\
0.12\end{array}$ & $\begin{array}{l}4.28 \pm \\
0.20^{\mathrm{a}}\end{array}$ & $\begin{array}{l}6.16 \pm \\
0.09^{\mathrm{a}}\end{array}$ & $\begin{array}{l}8.13 \pm \\
0.25^{\mathrm{a}}\end{array}$ & $\begin{array}{l}4.56 \pm \\
0.11^{\mathrm{a}}\end{array}$ & $\begin{array}{l}6.63 \pm \\
0.11^{\mathrm{a}}\end{array}$ & $\begin{array}{l}8.41 \pm \\
0.32^{\mathrm{a}}\end{array}$ \\
\hline Kidney & $\begin{array}{l}0.75 \pm \\
0.04\end{array}$ & $\begin{array}{l}0.82 \pm \\
0.04\end{array}$ & $\begin{array}{l}0.79 \pm \\
0.04\end{array}$ & $\begin{array}{l}0.80 \pm \\
0.06\end{array}$ & $\begin{array}{l}0.82 \pm \\
0.04\end{array}$ & $\begin{array}{l}1.02 \pm \\
0.15^{\mathrm{b}}\end{array}$ & $\begin{array}{l}1.79 \pm \\
0.04^{\mathrm{a}}\end{array}$ & $\begin{array}{l}0.82 \pm \\
0.07\end{array}$ & $\begin{array}{l}1.00 \pm \\
0.05^{\mathrm{b}}\end{array}$ & $\begin{array}{l}1.80 \pm \\
0.06^{\mathrm{a}}\end{array}$ \\
\hline Adrenal & $\begin{array}{l}1.92 \pm \\
0.06\end{array}$ & $\begin{array}{l}2.12 \pm \\
0.12\end{array}$ & $\begin{array}{l}1.73 \pm \\
0.06\end{array}$ & $\begin{array}{l}1.69 \pm \\
0.05\end{array}$ & $\begin{array}{l}1.61 \pm \\
0.04\end{array}$ & $\begin{array}{l}2.21 \pm \\
0.13\end{array}$ & $\begin{array}{l}2.49 \pm \\
0.07^{\mathrm{b}}\end{array}$ & $\begin{array}{l}1.65 \pm \\
0.09\end{array}$ & $\begin{array}{l}2.19 \pm \\
0.09\end{array}$ & $\begin{array}{l}2.43 \pm \\
0.08^{\mathrm{b}}\end{array}$ \\
\hline Testis & $\begin{array}{l}0.40 \pm \\
0.02\end{array}$ & $\begin{array}{l}0.39 \pm \\
0.01\end{array}$ & $\begin{array}{l}0.42 \pm \\
0.02\end{array}$ & $\begin{array}{l}0.43 \pm \\
0.02\end{array}$ & $\begin{array}{l}0.52 \pm \\
0.001\end{array}$ & $\begin{array}{l}0.65 \pm \\
0.03^{\mathrm{c}}\end{array}$ & $\begin{array}{l}0.95 \pm \\
0.02^{\mathrm{c}}\end{array}$ & $\begin{array}{l}0.51 \pm \\
0.01\end{array}$ & $\begin{array}{l}0.67 \pm \\
0.001 \mathrm{c}\end{array}$ & $\begin{array}{l}0.99 \pm \\
0.08^{\mathrm{c}}\end{array}$ \\
\hline
\end{tabular}

Values expressed as mean \pm S.E. for 6 determinations.

Probability evaluated by students ' $t$ ' test.

a $\mathrm{P}<0.001 ;$ b $\mathrm{P}<0.01 ;$ c $\mathrm{P}<0.05$.

$\mathrm{D}$ : Duration of treatment in days.

GR I : Basal diet.

GR II : $10 \%$ casein diet.

GR III : Basal diet $+\mathrm{MnCl}_{2} \cdot 4 \mathrm{H}_{2} \mathrm{O}, 15 \mathrm{mg} / \mathrm{kg}$.

GR IV : $10 \%$ casein diet $+\mathrm{MnCl}_{2} \cdot 4 \mathrm{H}_{2} \mathrm{O}, 15 \mathrm{mg} / \mathrm{kg}$.

\section{Discussion}

Retardation in growth, cachectic appearance and loss of fur in rats fed low protein diet (8\% casein) have been reported by Decastro and Boyd. ${ }^{9)}$ Morphological lesions in the form of degeneration and necrosis in liver, renal tubules, intestinal mucosa, pancreas, skin, salivary, thymus and thyroid glands have also been observed in these rats. ${ }^{10)}$ In the present investigation almost similar clinicopathological condition is found in rats fed 10\% casein diet. Further, this diet does not influence manganese induced morphological changes in various tissues of rats after their exposure to the metal for 45 days. It is perhaps due to almost identical increases in the metal contents of various tissues of manganese administered rats irrespective of the diet provided to them during the experimental period. This explanation receives support from our earlier observations that a correlation exists between the extent of morphological lesions and manganese content in brain, liver, kidney and testis.,11)

The data in the present study indicate that $10 \%$ casein diet to the adult rats for a period of 45 days does not alter the metabolism of manganese, when administered daily intraperitoneally $\left(\mathrm{MnCl}_{2} \cdot 4 \mathrm{H}_{2} \mathrm{O}, 15 \mathrm{mg} / \mathrm{kg}\right)$ for the same period. Thus protein deficiency 


\section{S.V. CHANDRA AND R.S. SRIVASTAVA}

to this extent does not render adult rats more susceptible to manganese toxicity. Further, long term experiments with varying concentration of proteins in the diet are required to rule out the possibility of protein deficiency as one of the metabolic factors responsible for individual susceptibility in manganese toxicity.

\section{ACKNOWLEDGEMENT}

Authors are grateful to Dr. S.H. Zaidi, Director, I.T.R.C. for his interest in this work. The technical assistance of Shri I. Ansari and S.G. Husain is gratefully acknowledgecl.

\section{REFERENCES}

1) Mena, I., Horuchi, K., Burke, K. and Cotzias, G.C. (1969). Neurology, 19, 1000-1006.

2) Chandra, Satya V. and Tandon, S.K. (1973). Environ. Physiol. Biochem. 3, 230-255.

3) Chandra, Satya V. and Shukla, G.S. (1976). Arch. Toxicol. 35, 319-323.

4) Shakman, R.A. (1974). Arch. Environ. Health, 28, 105-113.

5) Six, K.M. and Goyer, R.A. (1972). J. Lab. Clin. Med. 75, 128-136.

6) Ganther, H.E., Goudie, C., Sunde, M.L., Kopecky, M.J., Wagner, P., O.H. Sang Hwan and Hoekstra, W.G. (1972). Science, 175, 1122-1124.

7) Boyd, E.M. and Taylor, F.I. (1971). Toxicol. Appl. Pharmacol. 18, 158-167.

8) Shukla, G.S., Chandra, S.V. and Seth, P.K. (1976). Acta Pharmacol. Toxicol. 39, 562-569.

9) Boyd, E.M. and DeCastro, E.S. (1970). Ind. Med. Surg. 39, 229-236.

10) DeCastro, E.S. and Boyd, E.M. (1968). Bull. W.H.O. 38, 971-977.

11) Chandra, Satya V. and Srivastava, S.P. (1970). Acta Pharmacol. Toxicol. 28, 177-183. 